\begin{tabular}{c}
\hline KEMAS 12 (1) (2016) 150-156 \\
Jurnal Kesehatan Masyarakat
\end{tabular}

\title{
THE IMPLEMENTATION OF CREDENTIALING FOR FIRST-LEVEL HEALTH FACILITIES OF BADAN PENYELENGGARA JAMINAN SOSIAL (BPJS) KESEHATAN DENPASAR
}

\author{
Luh Putu Sinthya Ulandari ${ }^{\bowtie}$, Putu Ayu Indrayathi \\ Public Health Program, Medical Faculty, Udayana Universities
}

\section{Article Info \\ Article History: Submited January 2016 Accepted June 2016 Published July 2016 \\ Keywords: \\ primary health care; cre- dentialing; BPJS Kesehatan \\ DOI \\ http://dx.doi.org/10.15294/ \\ kemas.v12i1.4944}

\begin{abstract}
The implementation of credentialing program in JKN is different from the previous era, particularly for new medical facilities and medical provider of PT. Jamsostek and ASABRI. Therefore, this study aims at finding out the description associated with the process of credentialing implementation of the first-level health facilities from the perspective of PPK 1 and BPJS Kesehatan, Denpasar Branch. This research was conducted in January 2014 using qualitative approach. Data was collected through in-depth interviews to 11 medical facilities, as well as 2 executive credentialing teams from BPJS Kesehatan, Denpasar Branch. The subjects were selected purposively and the data was analyzed using thematic analysis. There are still some obstacles in the implementation of such credentialing program: there are still existing providers, especially TNI/Polri, which have the value below standard but are still contracted to serve JKN participants because the number is still relatively small. The new medical facilities have difficulty in self-assessment because there are many indicators that must be met, but the budget is limited. The study concludes that credentialing program has not yet fully applied the concept of managed care, thus regular monitoring to improve medical quality is needed.
\end{abstract}

\section{Introduction}

Health is one of basic needs of every human being to be able to live a decent and productive life as well as to improve their living standards. Health is also one indicator that determines a country's economic growth. Related to this, government is responsible for providing universal health care. Therefore, the government mandates the compulsory social security to the entire population, including through the National Health Insurance (Jaminan Kesehatan Nasional-JKN) which is arranged through a Social Security Agency (Badan Penyelenggara Jaminan Sosial-BPJS). In this case, PT. Askes is designated as BPJS. The goal is that all residents of Indonesia are covered by the insurance system, so that they can meet the basic needs of a decent public health.

The duties and authority held by BPJS in creating quality, effective and efficient health services are for example by determining the providers of medical facilities (faskes) as well as to assess the performance of providers, especially in first-level medical facilities considering that first-level medical faciliy is the gate keeper for providing health care to participants. To guarantee the quality of medical services that are relatively similar to all participants of the National Health Insurance (JKN), it is necessary to implement credentialing to all faskes which will cooperate with BPJS through some technical criteria that

\footnotetext{
Correspondece Address:

Public Health Program, Medical Faculty, Udayana Universities

PSKM Building, PB Sudirman Street Denpasar - Bali

Email : sinthyaulandari@yahoo.com
} 
include human resources, completeness of facilities and infrastructure, medical equipment and medicines, scope of services and service commitments.

The purpose of the credentialing implementation is to obtain medical facilities that are committed and able to provide health services effectively and efficiently through methods and assessment standards. Those standards must measurable with objectives that have been identified by the providers. Therefore, there will be no difference in the delivery of service which would affect the services satisfaction of patients.

The credentialing program implementation in transition period which is managed in the trimester III-IV in 2013 is not only implemented for the new medical facilities that will collaborate, but also is made to all medical facilities that have cooperated with PT. Askes, PT. Jamsostek, TNI and police. For medical facilities which were previously the providers of PT. Askes, of course, they have no difficulty in meeting the requirements of credentialing because the mechanisms and indicators are similar to the previous requirements. However, for medical facilities which are previously providers for PT. Social Security and TNI/Polri, this becomes a challenge because the credentialing process that they have done before is different from the required mechanism or indicators in the new regulation.

In a study conducted by Herkutanto and Astrid (2009), it is stated that one of the cornerstones of patient safety is the accountability of doctors involved in health care, where accountability is secured through a credential process. This is a process to provide clinical authority on a medical procedure. However, the credentialing implementation process in various institutions in Indonesia is still varied and not standardized. Responding to the above challenge, the researchers want to know the description of the credentialing implementation process of first-level medical facilities of BPJS Denpasar Branch which is seen from the provider side of first-level health facilities and the credentialing organizing body BPJS.

\section{Method}

This research was descriptive qualitative, describing the process of implementation of the first-level medical facilities credentialing BPJS Denpasar Branch. This research was conducted in Denpasar for 6 months starting from January to June 2014. The study population was the whole general practitioners, dentists and clinics pratama in Denpasar which had been registered as providers of first-level medical facilities BPJS Denpasar Branch as well as the staffs or officers at BPJS involved in the implementation process of credentialing. For January 2014, there were 37 physicians, 11 dentists, and 9 clinics pratama involved in the study.

The samples in this study were the credentialing organizing team BPJS Denpasar Branch, general practitioners, dentists and clinics pratama of BPJS Denpasar Branch which served in Denpasar. The criteria on the respondents included: a health care practices located in Denpasar, the provider status of first-level medical facilities of BPJS Denpasar Branch, Health Agency BPJS for credentialing organizers, and those who were willing to become respondents in this study and provided answers to all the questions in the interview guides.

The sampling technique in this study used purposive sampling, in this case, the researchers selected 13 respondents, with the following details: 2 staffs at the Health Services Management (MPK) BPJS and 11 providers FKTP BPJS with variations i.e.: two general practitioners who came from PT. Askes and PT. Jamsostek, two dentists from PT. Askes and PT. Jamsostek, as well as three clinics pratama derived from PT. Askes, PT. Jamsostek, and TNI / Polri. The data was gathered through indepth interviews and documentation study. Indepth interviews lasted \pm 45 minutes, and the type of questions used in-depth interviews was open questions. Then the qualitative data was analyzed using thematic analysis.

Thematic analysis was a process that could be used in a qualitative method, allowing the translation of symptoms/qualitative information into data based on qualitative research needs. Thematic analysis involved the process of information encoding, which could generate a list of themes, models of complex 
themes or indicators, qualifications related to the theme, or things between or a combination of those mentioned.

\section{Results and Discussion}

From the results of in-depth interviews, the dominant perception of the respondents regarding the credentialing implementation is an early stage that must be passed by all medical facilities who will join BPJS Kesehatan through the selection process of fulfilling requirements and service performance so that participants can be served optimally. Here is an excerpt of informants:

"well ... the goal is indeed for the sake of getting the first-level medical facilities which can serve participants BPJS maximally ... there will be services for all Indonesian people who use this insurance, especially in 2019, all people will be involved in JKN, both PBI and non PBI ... . "(informant 05-cash)

In the credentialing implementation, medical facilities which will conduct cooperation must meet several requirements including the requirements of the administrative and technical criteria. The standards set are usually minimal and mandatory standards or maximum standards and voluntary. Medical facilities that have met the standards set by the organizing body will be contracted to carry out tasks that have been set. This is consistent with the opinion of Smolenski (2005) who defines credentialing as a term in a process that is used to show an individual, program, institution or product in meeting the standards set by agencies (public or private) as the requirements for executing a task. Some literature suggests that the process of credentialing is an integrated system in medical services in many countries. According to Valenza et al (2005), even a Faculty of Dentistry in America, has implemented the credentialing system to ensure the competence of the teaching staff. According Herkutanto (2009), Indonesia requires credentials process to ensure accountability of medical workers. This process is a form of responsibility to the public health institutions for the trust given to ensuring patient safety

Credentialing not only aims to ensure and build professional quality of medical personnels/staffs by meeting the standard accreditation requirements but also to protect the service users or patients. In this case, credentialing policy will provide quality assurance services that are relatively similar for all Indonesians. Not only that, credentialing also serves to reduce the number of referrals from the CO level I to the CO level II, as before in cooperation with BPJS all first level health facilities consists of health centers, general practitioners, dentists, clinics pratama and Hospital Grade D Pratt must comply with the requirements and standards. The standards include the availability of human resources, the availability of medicines and medical equipment in order to provide health care services to participants in a comprehensive way. This is important to make sure that patients are not always referred to a health care in advanced level.

"I think, credentialing is a process to reduce referrals of patients to receive first level medical services...." (Infoman 11-DGA).

This is consistent with a research from Kesumawati (2012) who states that the unavailability of doctors in the health center/ Puskesmas, limited medicines for chronic diseases and the persistence of social Askes participants who do not carry health service flow correctly have become the precursor to the increasing number of referrals. Besides, the research from Zulkamain et al (2003) states that the perception factor medical needs, capacity of understanding, perception of financial risk also show the relationship and the influence of the high ratio of social health referral Askes in Banyumas.

Referral system can be done while the participants get sick and need an advanced health services. In this case, devolution of responsibility from PPK level I to PPK level II and PPK level III occurs. The medical care system with tiered referral patterns have been established by the BPJS Kesehatan with the hope that participants will gain health services effectively and efficiently in accordance with their needs. A high ratio of references will certainly affect the cost of service. According to Mukti et al (2001) in Kesumawati (2012), high 
ratio of references from RJTP Askes social will impact on the satisfaction of participants of Askes (Persero) and improve the utilization of advanced facilities outpatient service resulting in the reduction of medical service charge. This is also consistent with the opinion of Marisi (2012) in Kesumawati (2012) which states that the high referral rates of RJTP Askes social in Puskesmas will have an impact on the increase in hospital traffic numbers and will certainly affect the uncontrolled cost.

Credentialing process in an organization is very important to ensure competence and accountability. Credentialing process can effectively protect client and organization. This is important to prevent detrimental practices which can waste the cost and time associated with the process of implementation or service provision (Cassel \& Holmboe, 2006). In conducting credentialing BPJS, certain deficiencies are perceived by some providers of FKTP BPJS Kesehatan where several medical facilities (existing providers) have the value below the standard, but they are still contracted as providers of FKTP BPJS. Therefore, credentialing is only a screening process to determine the condition medical facilities in Denpasar, but has not been able to determine the quality of service of the medical facilities.

"... .. obviously, there are still many shortcomings from faskes because even though the value of the credentialing of existing medical facilities is still low, they are still contracted... This means that it's not the absolute price. Credentialing, I think, is just a screening, referring to the number of health facilities conditions in Denpasar, in Bali ... but does it determine the quality of service? This is still the big question"(Informant 04-dub).

At this transition, most implementation of credentialing is followed by the existing providers of PT. Askes, PT. Jamsostek, TNI and police. According to the results of interviews with one of the organizers of credentialing BPJS Denpasar Branch, the existing membership providers automatically become the providers of BPJS although they still have not met the requirements due to the previously existing providers have brought the participants.

"... ..the health facilities from
Jamsostek and TNI/Polriautomatically
become BPJS Kesehatan. Therefore,
whether they are eligible or not for
credentialing, they can still join BPJS
Kesehatan because they have brought
the participants for Jamsostek and
TNI/Polri... "(Informant BP01).

According to the results of interviews with the credentialing organizing body of BPJS Kesehatan, Denpasar Branch, specifically for existing providers from the military and police, most FKTP are newly established so they are difficult in completing the requirements and the regulations require them to have 2 years to the development and improvement. From the results of the assessment scores on selfassessment which has been done, almost all FKTP, particularly for healthcare facilities, are the existing providers who have followed the credentialing process which obtain a score $\geq 60$ and are accepted as a provider of firstlevel health facilities BPJS. Only for the TNI / Polri still obtain a score $<60$, but it receives proclamation by the regulations they have the opportunity to complete the requirements and clinical improvement.

"for the transition of credentialing, the problem remains only for TNI / Polri because they are new......so they are still developing their clinic performance. TNI / Polri do have medical officers, but they are mostly limited for specific context such as the conditions of war or anything like that so it is not like general clinics or health centers. So we give them two years to prepare better health facilities "(Informant BP01).

" all existing providers are accepted... if they are under the category, especially TNI / Polri, we give them excuse because they indeed have the chance to prepare their clinic improvement based on the regulations. This is because they are existing participants and existing health facilities. The Social Security and Askses have average of scores above 60, but if their score is under 60, we will tell them and ask them to 


$$
\text { improve it.. "(Informant BP02). }
$$

This is supported by the Ministry of Health Regulation No. 71 Year 2013 About Health Care In National Health Insurance, Article 40 points 1 and 2 which state that when this regulation is applied, all first level health facilities owned by TNI/Polri are considered as pratama clinic and should adjust to the pratama clinic licensing within a period of two (2) years after this regulation is implemented (Kemenkes RI, 2013). This also applies to the FKTP cooperating with BPJS Health, according to the Minister of Health Regulation No. 71 Year 2013 About Health Care In National Health Insurance, Article 41 point 1 which states that all first degree health facilities in collaboration with BPJS Kesehatan are excluded from accreditation obligations and must conform with the provisions of the five-year period.

The credentialing activity process which starts from the delivery/provision of credentialing form to the collection form makes informants think that they have received and collected the form prior to making the cooperation agreement. There are several obstacles that they face, namely: the deadline for form submission is very quick, the arrival of credentialing form is late because of the sender services, the senders deliver form in the morning or during the day when the doctors are not there.

When conducting the self-assessment, some of the informants come from providers FKTP BPJS Kesehatan Denpasar Branch find that they have difficulty in conducting selfassessment, in which they state that this is extremely difficult to do a self-assessment primarily to meet the requirements contained in credentialing form as the required large budget to provide complete equipment. They assume that the standards or requirements are too high and not worth the amount they will receive from the program.

"I honestly feel that this is something serious that we have to fill in like this, and not necessarily what we get is in accordance with what we have prepared. ... for general clinics and practice, my practice is actually included a somewhat hobbled because we're related to the budgetary costs of preparing the complete facility in accordance with the credentialing form "(Informant 04-dub).

For the new health facilities which have joined the Health BPJS, they tend to have a little capitation amount. Therefore, they feel that this is burdening in meeting the standards or requirements especially for supporting facilities. Most respondents state that the amount of capitation that they receive is small and not comparable to the workload and operating costs that they spend. This will certainly affect the level of job satisfaction of family doctors who will have an impact on the quality and performance of the service provider. Therefore, the need for considerations related to the welfare of health workers/service providers is important. In the study from Karyati et al (2004), 60.5\% shows that family doctors express low satisfaction of the capitation system. This is similar to the result of Chotimah' research (2000) stating that $73.57 \%$ of family doctors are not satisfied with the salary or wages earned in serving participants PT. Askes in East Java. In addition, it also obtained that the capitation system is one of the factors that influences job satisfaction and motivation of family doctor PT. Askes in providing health services.

Related to the validation conducted by the audit team through field visits, interviews obtained from several providers FKTP BPJS Denpasar Branch claim that they have received visitation from a team of independent audit that checks the availability of each indicator. However, there are those who state that they have not had any a visit by the audit team, with a variety of different reasons.

"Eemmhh ... they say that they will eventually come here. But in the meantime, they assess our answers first. They directly assess it... Oooo this faskes is allowed to participate and (if the score is) under 50, we are not allowed to participate. If from BPJS not yet ... according to the plan, they will send visitation letter, ... they say it will be these weeks.... "Informant 07-dgj). "I still have not received any visitation, but I am ordered to give the signature that I have already been visited. So I ask, why? because they see that mine is 
complete and they may already get the report from Jamsostek, so I say ok. ....I believe that I don't need to be checked. But there are some friends who are visited, and checked ... "Informant 10DUJ)

This is in contrary to the opinion of the credentialing organizing body of BPJS Denpasar Branch which states that all first-level medical facilities BPJS that pass through the credentialing will be visited by the assessment team to do validation of self-assessment done by the health facilities.

"... all health facilities which have already done credentialing must be visited, more or less to match with what they have made in the self-assessment with the real conditions " (Informant BP02).

Related to this, it is necessary to do the monitoring and evaluation of the credentialing implementation, not only on the providers of medical facilities but also from the organizing body to measure the achievement of results or performance of the program. This is consistent with the results of research from Herkutanto and Astrid (2009), in which the FGD participants state that the credentials have not been ideal. The expectations of participants are reflected in the needs being expressed in the FGD namely the standardization of rules and instruments credentials, the needs of the monitoring process, good relations team credentials with management, as well as the needs of the team are the ideal credentials. In addition, participants also underline that good relations between colleagues is very important to be maintained.

Related to the validation and scoring of credentialing form conducted by the organizers, from interviews with credentialing team BPJS Denpasar Branch, it is obtained that all FKTP BPJS have already done selfassessment and received the visits from the audit team. They state that the results of field visits conducted are not far in contrast to the results of self-assessment that has been done by health facilities.

"Emmm .... to fill in the form, it is indeed done, but it usually concerns with the empty points. So, it means that they do not fill the points although the facilities exist in the clinic. But, for the unnecessary or overstating addition, it doesn't exist"(Informant BP01).

In the implementation during the transition period, BPJS has not yet fully applied the concept of managed care effectively because there are still medical facilities which do not meet the criteria but are contracted and paid adequately to serve the participants. This is similar to the research from Sani et al (1998) which states that PT. Askes West Sumatra have not implemented the whole concept of managed care, one of which is that PT. Askes West Sumatra does not have any criteria on the establishment of a medical care facility to be designated as the service provider, where it is not in accordance with the principles of quality criteria in the concept of managed care. In this case, the concept of managed care refers to a concept of health that integrates the financing and delivery of health services in their contracts with health care providers, their quality improvement programs and study utilization of services, their standards in health care, and the health care system that are effective and efficient so that participants can benefit health care and protection to meet basic health needs.

Hence, from the above conditions, the lack of equality of service provided by each firstlevel health facilities toward participants JKN exists. Therefore, monitoring on a regular basis and providing an appeal or warning especially to the provider FKTP BPJS which do not meet the requirements are important in order to make improvements and developments for quality of medical care.

\section{Conclusion}

This study shows that the credentialing implementation during transition period has not yet fully applied the concept of managed care because there are some first-level medical facilities especially those which are existing providers such as military / police have not met the requirements but are contracted and paid adequately to serve the participants. This is because the numbers of medical facilities that exist at the time are still small in number, so 
the organizing body gives excuse and they give the opportunity for faskes to conduct clinical development and improvement 2 years. Such conditions will certainly lead to differences in the quality of service that will be provided to participants JKN. In addition, for new medical facilities, the credentialing implementation is currently perceived to be quite difficult, especially in meeting the indicators/ requirements as they relate to large budget in completing the tools and facilities, whereas the amount of capitation that they will receive is not worth the cost they spend to provide such complete facilities.

\section{Acknowledgement}

The gratitude from the author goes to the first-level medical facility BPJS Kesehatan Denpasar Branch, the credentialing organizing body of BPJS Denpasar Branch, The Head of National Unity of Politics and Public Protection Denpasar which have given permission for the conduct of research, as well as all the colleagues who have helped the success of this research.

\section{References}

Cassel, C. K., \& Holmboe, E. S. (2006). Credentialing and Public Accountability. Journal of the American Medical Association, 295(8): 939940.

Chotimah. (2000). Fakto-Faktor yang Mempengaruhi Kepuasan Kerja dan Motivasi Dokter Keluarga PT. Askes dalam Memberikan Pelayanan Kesehatan. Jurnal Manajemen Pelayanan Kesehatan, 3(4): 86 171

Herkutanto, Susilo, AP. (2009). Hambatan dan Harapan Sistem Kredensial Dokter: Studi Kualitatif di Empat Rumah Sakit Indonesia.
Jurnal Manajemen Pelayanan Kesehatan, 12(3): $140-147$.

Herkutanto. (2009). Profil Komite Medis di Indonesia dan Faktor-Faktor yang Mempengaruhi Kinerjanya dalam Menjamin Keselamatan Pasien. Jurnal Manajemen Pelayanan Kesehatan, 2(1) : 41-7.

Karyati M, Mukti AG, Nusyirwan MS. (2004). Tingkat Kepuasan Dokter Keluarga Terhadap Sistem Pembayaran Kapitasi PT. Askes di Kota Medan. Jurnal Manajemen Penalayan Kesehatan, 7 (2): 81 - 87.

Kemenkes RI. (2013). Peraturan Menteri Kesehatan Nomor 71 Tahun 2013 tentang Pelayanan Kesehatan Pada Jaminan Kesehatan Nasional. Jakarta: Kementrian Kesehatan RI.

Kesumawati, Ima Nur. (2012). Analisis Pelaksanaan Rujukan RJTP Peserta Askes Sosial PT.Askes (Persero) Kantor Cabang Sukabumi di Puskesmas Nanggeleng dan Gedong Panjang Tahun 2012. Fakultas Kesehatan Masyarakat, Universitas Indonesia.

Sani SH, Prawitasari JE, Mukti AG. (1998). Evaluasi Penerapan Konsep Managed Care dalam Program PT. Askes Indonesia Kantor Cabang Sumatera Barat. Jurnal Manajemen Pelayanan Kesehatan, 1(3):121 - 131.

Smolenski, M. C. (2005). Credentialing, Certification, and Competence: Issues for New and Seasoned Nurse Practitioners. Journal of the American Academy of Nurse Practitioners, 17 (6): 201-204.

Valenza JA, George LA, O’Neil PN. (2005). A Model for Clinical Credentialing of Dental School Faculty, Journal of Dental Education, 69(8).

Zulkamain, et al. (2003). Faktor - faktor yang Mempengaruhi Rujukan Rawat Jalan Tingkat Pertama Peserta Wajib PT. Askes di Kabupaten Banyumas. Jurnal Manajemen Pelayanan Kesehatan, 6(2). 